\title{
Kajian Adverse Drug Reactions Terkait Interaksi Obat di Bangsal Rawat Inap Rumah Sakit Akademik UGM
}

\author{
Study on Adverse Drug Reactions Related to Drug Interactions on Medical Ward Teaching Hospital UGM
}

\author{
Fivy Kurniawati ${ }^{1 *}$, Nanang Munif Yasin ${ }^{1}$, Amila Dina ${ }^{2}$, Sanses Atana², Sarah Nabila Hakim² \\ 1. Departemen Farmakologi dan Farmasi Klinis, Fakultas Farmasi, Universitas Gadjah Mada, Yogyakarta, Indonesia \\ 2. Program Sarjana Program Studi Farmasi, Fakultas Farmasi, Universitas Gadjah Mada, Yogyakarta, Indonesia \\ Submitted: 29-09-2020 Revised: 23-10-2020 Accepted: 30-12-2020 \\ Korespondensi : Fivy Kurniawati : Email : fivy_k@ugm.ac.id
}

\begin{abstract}
ABSTRAK
Adverse Drug Reactions (ADRs) merupakan salah satu penyebab pasien harus memperpanjang lama rawat inap dan interaksi obat termasuk salah satu penyebab terjadinya ADRs. ADR terkait interaksi obat menjadi permasalahan klinis sehingga membutuhkan pencegahan yang tepat. Penelitian ini bertujuan untuk mengidentifikasi potential interaksi obat dan mengidentifikasi Adverse Drug Reactions (ADRs) terkait interaksi obat pada pasien rawat inap di Rumah Sakit Akademik Universitas Gadjah Mada. Penelitian ini merupakan penelitian cross-sectional dengan pengambilan data secara retrospektif melalui rekam medis pasien periode Januari-Juni 2018. Populasi dalam penelitian ini adalah semua pasien yang mendapatkan terapi obat dua atau lebih secara bersamaan dan dirawat di bangsal rawat inap Rumah Sakit Akademik Universitas Gadjah Mada, Yogyakarta, Indonesia. Data yang diperoleh kemudian dianalisis secara deskriptif. Interaksi obat dianalisis menggunakan Drug Interaction Facts 2012 dan Stockley. ADRs dianalisis dengan mengamati efek yang terdokumentasi pada pasien akibat interaksi obat yang tercantum dalam literatur. Kejadian interaksi obat yang potensial terjadi pada pasien rawat inap RS Akademik UGM periode Januari-Juni 2018 yaitu sebanyak 115 dari 362 pasien (31,8\%) dengan jumlah kejadian interaksi sebanyak 182 interaksi obat. Jenis interaksi obat yang paling banyak terjadi adalah interaksi moderate sejumlah 115 interaksi (63,2\%), dan mekanisme interaksi terbanyak yaitu unknown (54,4\%). Aktual ADRs yang terjadi akibat interaksi obat adalah 3,3\% yakni 2 kejadian pada pasien pediatri dan 4 kejadian pada pasien geriatri. Penelitian ini dapat menjadi sumber informasi mengenai interaksi obat dan ADRs serta panduan bagi apoteker dan tenaga kesehatan dalam pemilihan pengobatan yang tepat.
\end{abstract}

Kata kunci: ADRs; interaksi obat; pasien rawat inap; rumah sakit

\section{ABSTRACT}

Adverse Drug Reactions (ADRs) is one of the causes of patient's prolonged length of stay in the hospital and drug interactions can be included as one of the causes of the cause of ADRs. ADR related to drug interactions is a clinical problem that requires proper prevention. This study aimed to identify potential drug interactions also identify adverse drug reactions (ADRs) related to drug interactions in hospitalized patients at Universitas Gadjah Mada Teaching Hospital. This cross-sectional study used retrospective data collection through patient's medical records from January to June 2018. Patients included in this study were all patients who received therapy more than two kind of drugs simultaneously treated in hospital wards of Universitas Gadjah Mada Teaching Hospital, Yogyakarta, Indonesia. The data collected were then analyzed descriptively. Drug interactions were analyzed using Drug Interaction Facts 2012 and Stockley. ADRs were analyzed by monitoring documented effects of patients with potential drug interaction. There were 115 of 362 patients (31.8\%) with potential drug interactions. The total numbers of potential interactions that occur were 182 interactions. The most potential type of interaction was the interaction with moderate severity, with 115 interactions (63.2\%). The majority of drug interactions occur through unknown mechanisms (54.4\%). Actual ADR occurs in 3.3\% patients who were 2 pediatric patients and 4 geriatric patients. This study can be a reference for drug interactions and ADRs as well as guide for pharmacist and healthcare in providing the right medication.

Keywords: ADRs; drug interactions; inpatients; hospital 


\section{PENDAHULUAN}

Adverse Drug Reactions (ADR) adalah respon terhadap suatu obat yang merugikan, tidak diinginkan, dan terjadi pada dosis yang biasanya digunakan pada manusia untuk pencegahan, diagnosis, terapi penyakit, atau untuk modifikasi fungsi fisiologik. ${ }^{1}$ Kejadian ADRs menyebabkan 5\% admisi rumah sakit, $28 \%$ gawat darurat, dan 5\% kematian di rumah sakit. ${ }^{2}$ Kerentanan seseorang terhadap ADR tergantung pada usia, kehamilan, jenis kelamin, status penyakit, dan polifarmasi. ${ }^{3}$

Salah satu penyebab dari kejadian Adverse Drug Reactions adalah interaksi obat. ${ }^{4}$ Beberapa penelitian lain menunjukkan bahwa sebanyak $4,62 \%$ dan $8,7 \%{ }^{6}$ pasien dengan potensial interaksi obat mengalami ADRs, bahkan lebih dari 20\%.2 Kematian yang disebabkan oleh ADR akibat interaksi obat lebih dari 100.000 tiap tahun. ${ }^{7}$ Tenaga kesehatan sering tidak menyadari risiko klinis kombinasi obat tertentu. ${ }^{5}$

Kasus kegagalan terapi yang dapat dicegah akibat interaksi obat di dunia masih cukup tinggi. ${ }^{8}$ Berdasarkan WHO Global Individual Case Safety Report database, selama periode 20 tahun ditemukan 3766 kasus yang dilaporkan berhubungan dengan interaksi obat. 5, 9 Di Amerika Serikat, sekitar 195.000 pasien rawat inap mengalami interaksi obat tiap tahunnya. Di Meksiko sebanyak 5,6\% hingga $63 \%$ masalah terkait pengobatan disebabkan oleh interaksi obat. 10, 11 Dari pemeriksaan pasien rawat inap pada 2011, $49 \%$ berhubungan dengan $\geq 1$ potensi interaksi obat - obat. ${ }^{12}$ Angka kejadian interaksi obat di Indonesia belum diperoleh angka pasti karena dokumentasi interaksi obat belum berjalan optimal sehingga pengkajian interaksi obat belum bisa dilakukan secara menyeluruh. ${ }^{13}$ Salah satunya, pada pasien rawat inap pediatri di suatu rumah sakit di wilayah Kalimantan Selatan menunjukkan sebanyak $26,34 \%$ resep mengalami interaksi obat. ${ }^{14}$ Sementara studi epidemiologi di salah satu rumah sakit Semarang menunjukkan bahwa satu pertiga pasien mengalami polifarmasi dan 15\% diantaranya mengalami interaksi obat yang berbahaya, yaitu sebanyak $62 \%$ mengalami satu kejadian interaksi obat, sementara 38\% lainnya mengalami dua atau lebih kejadian interaksi. ${ }^{11}$ Dalam prakteknya, interaksi obat merupakan hal yang biasa ditemukan pada penggunaan kombinasi obat. Tidak semua interaksi obat pasti terjadi pada pasien (interaksi obat - obat potensial), namun identifikasi terhadap interaksi obat dibutuhkan karena dapat meningkatkan resiko terjadinya reaksi obat yang tidak diingikan atau adverse drug reactions, menurunkan efikasi terapi, dan terjadinya toksisitas. 15 Penelitian ini bertujuan untuk mengidentifikasi kejadian interaksi obat, jenis dan mekanisme interaksi obat, dan kejadian ADRs terkait interaksi obat pada terapi pasien rawat inap Rumah Sakit Akademik Universitas Gadjah Mada.

\section{METODE}

Penelitian ini merupakan penelitian cross-sectional. Data dikumpulkan secara retrospektif dari rekam medis pasien lalu dianalisis secara deskriptif. Tempat pengambilan sampel berada di Bagian Rekam Medis RS Akademik UGM.

Seluruh pasien rawat inap RS Akademik UGM periode Januari hingga Juni 2018 dicatat berdasarkan kriteria inklusi dan eksklusi. Kriteria inklusi penelitian ini adalah pasien rawat inap yang mendapat $\geq 2$ jenis obat secara bersamaan dan dirawat lebih dari satu hari. Pasien dengan rekam medis yang tidak lengkap pada bagian regimen pengobatan dan memperoleh $<2$ jenis obat selama rawat inap dieksklusi.

Penentuan ukuran sampel dihitung menggunakan rumus Lemeshow. Jumlah sampel minimal yang diambil sebanyak 96 subjek pasien. Pengambilan sampel ditentukan dengan simple random sampling. Total populasi pasien RS Akademik UGM periode Januari hingga Juni 2018 adalah 3.483 pasien. Selanjutnya dilakukan random data menggunakan formula RAND pada Microsoft Excel. Selanjutnya nomor rekam medik pasien yang terpilih pada proses random sampling dilakukan pengambilan data melalui rekam medis pasien. Total subjek yang diambil 
Fivy Kurniawati, et al

Tabel I. Karakteristik Pasien

\begin{tabular}{lcc}
\hline Karakteristik & $\begin{array}{c}\text { Jumlah Pasien (\%) } \\
\mathbf{n}=\mathbf{3 6 2}\end{array}$ & $\begin{array}{c}\text { Jumlah Interaksi Obat (\%) } \\
\mathbf{n = 1 1 5}\end{array}$ \\
\hline Jenis Kelamin & $192(53,0 \%)$ & $61(53 \%)$ \\
$\quad$ Laki-laki & $170(47,0 \%)$ & $54(47 \%)$ \\
$\quad$ Perempuan & & \\
Usia & $122(33,7 \%)$ & $30(26,1 \%)$ \\
$\quad$ Pediatri (<18 tahun) & $120(33,1 \%)$ & $45(39,1 \%)$ \\
Dewasa (18-64 tahun) & $120(33,1 \%)$ & $40(34,8 \%)$ \\
Geriatri $(\geq 65$ tahun) & & \\
Lama Rawat Inap & $190(52,5 \%)$ & $41(35,6 \%)$ \\
$2-3$ & $133(36,7 \%)$ & $57(49,6 \%)$ \\
$4-7$ & $39(10,8 \%)$ & $17(14,8 \%)$ \\
$>7$ & & \\
Jumlah Obat & $97(26,8 \%)$ & $15(13,0 \%)$ \\
$<5$ & $213(58,8 \%)$ & $71(61,7 \%)$ \\
$5-10$ & $52(14,4 \%)$ & $29(25,3 \%)$ \\
$>10$ & & \\
\hline
\end{tabular}

sejumlah 403 pasien dan sebanyak 362 pasien memenuhi kriteria

Persetujuan izin etik diperoleh dari institusi lokal tempat studi dilakukan dan dari komite etik Fakultas Kedokteran Universitas Gadjah Mada, Yogyakarta, Indonesia. Nomor izin ethical clearance penelitian ini yaitu KF/FK/0820/EC/2018. Informasi pasien dikumpulkan atas izin Rumah Sakit Pendidikan Universitas Gadjah Mada.

Data karakteristik pasien dianalisis secara deskriptif dan ditampilkan dalam bentuk persentase. Jenis interaksi dan mekanisme interaksi obat dianalisis menggunakan Drug Interaction Facts 2012 dan Stockley. Berdasarkan jenisnya, interaksi obat diklasifikasikan menjadi major, moderate dan minor. Interaksi major dapat menyebabkan kecacatan permanen bahkan kematian, interaksi moderate dapat menyebabkan penurunan kondisi pasien yang memerlukan perawatan dan interaksi minor dapat memberikan efek yang tidak terlalu berpengaruh terhadap kondisi pasien. ADRs dianalisis dengan mengamati efek yang terdokumentasi pada pasien akibat interaksi obat yang tercantum dalam literatur. Aktual ADR adalah efek merugikan yang dialami pasien akibat interaksi obat yang digunakan pada hari yang sama dan diketahui melalui keluhan, tanda-tanda vital serta uji laboratorium pasien, sementara potensial ADR adalah efek merugikan akibat interaksi obat yang potensial terjadi dialami pasien berdasarkan literatur.

\section{HASIL DAN PEMBAHASAN}

Data pasien diambil dari populasi pasien rawat inap RS Akademik UGM periode Januari-Juni 2018 dengan total 3483 rekam medis yang selanjutnya dipilih menggunakan metode simple random sampling. Pada penelitian ini, jumlah sampel data pasien yang diambil dan memenuhi kriteria inklusi dan eksklusi sejumlah 362 pasien. Data yang diperoleh kemudian dikaji mengenai karakteristik pasien, potensial interaksi obat yang terjadi serta kejadian adverse drug reactions terkait interaksi obat.

\section{Karakteristik Pasien}

Tabel I menunjukkan bahwa pasien rawat inap yang berpotensi terjadi interaksi obat adalah laki-laki (53\%). Pasien geriatri yang menjalani rawat inap di Meksiko sebanyak $61 \%$ berjenis kelamin laki-laki. ${ }^{16}$ Penelitian lain di RS Pendidikan Surabaya 
menyebutkan bahwa potensial interaksi lebih banyak pada pasien laki-laki. ${ }^{17}$ Meskipun demikian, jenis kelamin tidak memiliki efek signifikan terhadap interaksi obat. ${ }^{4}$

Rata-rata lama rawat inap pasien adalah 4-7 hari dengan status keluar membaik. Lama rawat inap penelitian lain menunjukkan paling banyak yakni 4-5 hari.18, 19 Pasien dengan lama rawat inap lebih panjang memiliki kemungkinan terhadap kejadian interaksi obat lebih tinggi dibandingkan pasien dengan lama rawat inap lebih pendek. ${ }^{20}, 21,22,23$ Begitu pula dengan hasil penelitian ini yang menunjukkan pasien mengalami kejadian interaksi obat lebih banyak pada lama rawat inap yang lebih panjang. Diagnosis utama paling banyak pada pasien rawat inap RS Akademik UGM adalah penyakit sistem sirkulasi sejumlah 50 pasien $(13,7 \%)$ antara lain cerebral infarction, stroke, stemi inferior, congetive heart failure (CHF), dan unstable angina.

Jumlah obat yang diresepkan paling banyak berkisar pada rentang yakni 5-10 jenis obat $(61,7 \%)$ setiap pasien, yang menggambarkan bahwa kejadian interaksi obat semakin meningkat dengan banyaknya macam terapi yang diberikan. Hal sama juga ditunjukkan pada penelitian dengan 32,3\% pasien mendapat 5 atau lebih macam obat.7, 14, ${ }^{24}$ Hasil lain juga menunjukkan sebanyak lebih dari $40 \%$ menggunakan lima atau lebih obat dan sebanyak $12 \%$ menggunakan 10 atau lebih banyak obat dan tidak sesuai dengan kebutuhannya. ${ }^{25}$ Semakin banyak jumlah obat yang digunakan dalam waktu yang bersamaan akan menimbulkan potensi interaksi obat yang lebih besar. $26,27,28,29$ Secara signifikan, risiko interaksi akan meningkat pada 3-5 obat sampai 6 atau lebih obat yang diresepkan. ${ }^{30}$

\section{Potensial Interaksi Obat}

Sejumlah 115 dari 362 pasien $(31,8 \%)$ berpotensi mengalami interaksi obat (Tabel I). Hal serupa juga ditemukan pada penelitian dengan potensi interaksi obat sebesar $25,8 \%{ }^{21}$ dan pada penelitian lain dengan $38,6 \% 13$ interaksi obat. Jumlah total potensial interaksi yang terjadi sebanyak 182 interaksi. Pada penelitian ini, jumlah potensial interaksi obat tidak jauh berbeda pada tiap rentang usia. Secara statistik, tidak ada perbedaan signifikan antara pengaruh usia dan potensial interaksi obat. ${ }^{4,14}$ Akan tetapi, usia merupakan salah satu faktor risiko ADR. Parameter farmakokinetik dan farmakodinamik akan berubah seiring bertambahnya usia sebagai akibat dari perubahan anatomi tubuh yang terjadi. ${ }^{5}$ Hal tersebut dapat dilihat pada penelitian ini yakni aktual ADR akibat interaksi obat hanya terjadi pada pasien pediatri dan geriatri yang memiliki faktor resiko ADR lebih tinggi.

Interaksi obat dianalis menjadi tiga tipe, yaitu major, moderate, dan minor (Tabel II). Dari total 115 pasien, terdapat 182 potensial interaksi obat yang terjadi, terdiri dari 8 interaksi major, 115 interaksi moderate, dan 59 interaksi minor. Penelitian lain menunjukkan tingkat kejadian interaksi obat di salah satu Rumah Sakit di Kota Palu yaitu mayor 15 (6,53\%), moderate $112(48,69 \%)$ dan minor 103 $(44,78 \%){ }^{31}$

Obat yang diperoleh 37 pasien dan paling banyak berpotensi mengalami interaksi adalah ketorolak-ranitidin. Interaksi moderate antara sefotaksim-gentamisin dan gentamisinketorolak berada pada urutan terbanyak berikutnya dengan jumlah yang sama, yaitu 24 pasien.

Interaksi major merupakan jenis interaksi yang dapat menyebabkan kerusakan yang mengancam jiwa atau kerusakan permanen. ${ }^{32}$ Interaksi $\mathrm{KCl}$-spironolakton dapat menimbulkan efek hiperkalemia berat. Pasien disarankan untuk tidak menggunakan kombinasi ini kecuali ada bukti terdokumentasi bahwa pasien memiliki gejala klinis yang tidak responsif terhadap salah satu obat saja. Manajemen untuk interaksi ini adalah dengan memantau serum kalium pasien secara berkala dan melakukan dietary counseling. Sementara interaksi isoniazidrifampisin dapat meningkatkan risiko hepatotoksik. ${ }^{18}$ Interaksi isoniazid-rifampisin juga ditemukan pada penelitian lain sebagai interaksi major terbanyak. ${ }^{24}$ 
Fivy Kurniawati, et al

Tabel II. Tipe Interaksi Obat

\begin{tabular}{llcc}
\hline Tipe & \multicolumn{1}{c}{ Obat yang Berinteraksi } & Sig. & $\begin{array}{c}\text { Jumlah (\%) } \\
\mathbf{n = 1 8 2}\end{array}$ \\
\hline Major & Kalium Klorida-Spironolakton & $\mathbf{1}$ & $\mathbf{2 ( 1 , 1 0 \% )}$ \\
& Isoniazid-Rifampisin & $\mathbf{1}$ & $\mathbf{2}(\mathbf{1 , 1 0} \%)$ \\
& Aspirin-Ibuprofen & 1 & $1(0,55 \%)$ \\
& Aspirin-Ketorolak & 1 & $1(0,55 \%)$ \\
\multirow{4}{*}{ Moderate } & Kandesartan-Spironolakton & 1 & $1(0,55 \%)$ \\
& Allopurinol-Kaptopril & 4 & $1(0,55 \%)$ \\
& Gentamisin-Ketorolak & $\mathbf{2}$ & $\mathbf{2 4}(\mathbf{1 3 , 1 9 \% )}$ \\
& Sefotaksim-Gentamisin & $\mathbf{2}$ & $\mathbf{2 4}(\mathbf{1 3 , 1 9 \% )}$ \\
& Ampisillin- Gentamisin & 2 & $14(7,69 \%)$ \\
Minor & Alprazolam-Atorvastatin & 4 & $4(2,20 \%)$ \\
& Asam Folat-Fenitoin & 2 & $4(2,20 \%)$ \\
& Ketorolak-Ranitidin & $\mathbf{5}$ & $\mathbf{3 7}(20,33 \%)$ \\
& Furosemid-Parasetamol & 5 & $5(2,75 \%)$ \\
\hline
\end{tabular}

Interaksi obat dengan tingkat keparahan moderate paling banyak berpotensi terjadi, yaitu sebesar $63,19 \%$ dari total interaksi. Interaksi moderate terbanyak ditemukan pada penelitian lain, yaitu 53\% dari seluruh pasien. ${ }^{33}$ Potensial interaksi moderate paling banyak ditemukan pada pasien yang mendapatkan sefotaksimgentamisin dan gentamisin-ketorolak. Interaksi sefotaksim dan gentamisin berisiko meningkatkan risiko nefrotoksik akibat peningkatan efek bakterisida. Gentamisin dan ketorolak yang digunakan bersamaan dapat menyebabkan peningkatan konsentrasi plasma gentamisin. Sehingga perlu pemantauan fungsi ginjal dan kadar gentamisin serta penurunan dosis jika diperlukan. ${ }^{18}$

Jumlah potensial interaksi minor adalah $23(12,64 \%)$ interaksi, dengan obat yang paling banyak berinteraksi, yaitu ketorolak-ranitidin. Efek terapeutik ketorolak dapat berubah jika digunakan bersamaan dengan ranitidin. Perubahan efek tersebut berupa peningkatan konsentrasi plasma ketorolak yang dapat meningkatkan risiko pendarahan. ${ }^{34}$

Potensial interaksi obat dikelompokkan pula berdasarkan mekanismenya pada Tabel III, yaitu 6 perubahan absorbsi, 28 perubahan metabolisme, 37 perubahan ekskresi, 12 farmakodinamik, dan 99 unknown.
Berdasarkan acuan Drug Interaction Facts 2012, mayoritas interaksi yang terjadi belum diketahui mekanismenya secara pasti (54,4\%). Penelitian lain menunjukkan mekanisme interaksi terbanyak yang terjadi yaitu pada fase metabolisme sebesar 35,4\%. ${ }^{13}$

Mekanisme interaksi obat merupakan bagaimana suatu obat dapat berinteraksi dan mempengaruhi aksi obat lainnya secara farmakokinetik dan farmakodinamik. ${ }^{18}$ Penelitian ini menunjukkan bahwa sebanyak $54,7 \%$ potensial interaksi terjadi melalui mekanisme yang belum diketahui secara pasti (unknown). Paling banyak ditemukan pada pasien yang mendapat obat ketorolakranitidin secara bersamaan. Penggunaan keduanya bersamaan dapat mengubah efek terapeutik ketorolak. Akan tetapi, mekanisme yang terjadi antara kedua obat ini belum diketahui. Kedua obat ini tidak membutuhkan monitoring khusus apabila digunakan bersamaan. ${ }^{18}$

\section{Adverse Drug Reactions terkait Interaksi Obat}

Beberapa pasien dapat mengalami efek yang tidak diinginkan setelah mengonsumsi suatu kombinasi obat pada dosis normal. ${ }^{35}$ Potensial ADR pada penelitian ini merupakan efek interaksi obat yang merugikan pasien berdasarkan studi pustaka Drug Interaction 
Tabel IIIa. Mekanisme Interaki Obat

\begin{tabular}{|c|c|c|c|c|}
\hline Interaksi & $\begin{array}{c}\text { Jumlah (\%) } \\
n=182\end{array}$ & Mekanisme & Efek & Manajemen \\
\hline \multicolumn{5}{|c|}{ Perubahan Absorbsi } \\
\hline $\begin{array}{l}\text { Parasetamol- } \\
\text { Triheksifenidil }\end{array}$ & $2(1,10 \%)$ & $\begin{array}{l}\text { Absorpsi } \\
\text { parasetamol } \\
\text { yang tertunda } \\
\text { pada saluran } \\
\text { cerna oleh } \\
\text { antikolinergik }^{1}\end{array}$ & $\begin{array}{l}\text { Onset } \\
\text { parasetamol } \\
\text { tertunda atau } \\
\text { menurun Error! } \\
\text { Bookmark not defined. }\end{array}$ & $\begin{array}{l}\text { Parasetamol dan } \\
\text { antikolinergik } \\
\text { dapat diberikan } \\
\text { bersamaan dengan } \\
\text { sedikit atau tanpa } \\
\text { resiko klinis Error! } \\
\text { Bookmark not defined. }\end{array}$ \\
\hline \multicolumn{5}{|c|}{ Perubahan Metabolisme } \\
\hline $\begin{array}{l}\text { Alprazolam- } \\
\text { Atorvastatin }\end{array}$ & $4(2,20 \%)$ & $\begin{array}{l}\text { Penurunan } \\
\text { metabolisme } \\
\text { oksidatif } \\
\text { alprazolamError! } \\
\text { Bookmark not defined. }\end{array}$ & $\begin{array}{l}\text { Efek alprazolam } \\
\text { meningkat dan } \\
\text { berkepanjangan } \\
\text { Error! Bookmark not } \\
\text { defined. }\end{array}$ & $\begin{array}{l}\text { Pemantauan } \\
\text { terhadap depresi } \\
\text { pernapasan dan } \\
\text { sedasiError! Bookmark not } \\
\text { defined. }\end{array}$ \\
\hline $\begin{array}{l}\text { Parasetamol- } \\
\text { Fenitoin }\end{array}$ & $3(1,66 \%)$ & $\begin{array}{l}\text { Peningkatan } \\
\text { metabolisme } \\
\text { parasetamolError } \\
\text { ! Bookmark not defined. }\end{array}$ & $\begin{array}{l}\text { Peningkatan } \\
\text { potensi } \\
\text { hepatotoksisitas } \\
\text { Error! Bookmark not } \\
\text { defined. }\end{array}$ & $\begin{array}{l}\text { Tidak memerlukan } \\
\text { penyesuaian dosis } \\
\text { pada dosis terapi } \\
\text { normalError! Bookmark not } \\
\text { defined. }\end{array}$ \\
\hline $\begin{array}{l}\text { Fenobarbital- } \\
\text { Asam Valproat }\end{array}$ & $3(1,65 \%)$ & 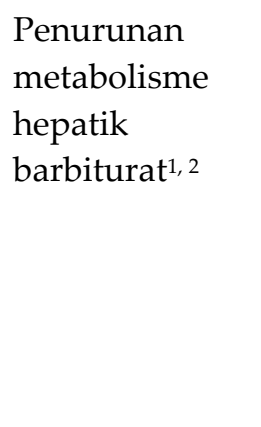 & $\begin{array}{l}\text { Peningkatan } \\
\text { konsentrasi } \\
\text { plasma } \\
\text { barbiturat, } \\
\text { meningkatkan } \\
\text { efek } \\
\text { farmakologi dan } \\
\text { adverse effect }{ }^{\text {Error! }} \\
\text { Bookmark not defined. }\end{array}$ & $\begin{array}{l}\text { Pemantauan } \\
\text { konsentrasi plasma } \\
\text { barbiturat, } \\
\text { penurunan dosis } \\
\text { jika perlu }{ }^{\text {Error! Bookmark }} \\
\text { not defined.,Error! Bookmark } \\
\text { not defined. }\end{array}$ \\
\hline $\begin{array}{l}\text { Isoniazid- } \\
\text { Rifampisin }\end{array}$ & $2(1,10 \%)$ & $\begin{array}{l}\text { Perubahan } \\
\text { metabolisme } \\
\text { isoniazid }{ }^{\text {Error! }} \\
\text { Bookmark not } \\
\text { defined.,Error! } \\
\text { Bookmark not defined. }\end{array}$ & $\begin{array}{l}\text { Hepatotoksisitas } \\
\text { Error! Bookmark not } \\
\text { defined.,Error! Bookmark } \\
\text { not defined. }\end{array}$ & $\begin{array}{l}\text { Tidak perlu } \\
\text { penyesuaian atau } \\
\text { pemantauan pada } \\
\text { sosis terapi oralError! } \\
\text { Bookmark not defined.,Error! } \\
\text { Bookmark not defined. }\end{array}$ \\
\hline $\begin{array}{l}\text { Metil } \\
\text { prednisolon- } \\
\text { Fenitoin }\end{array}$ & $2(1,10 \%)$ & $\begin{array}{l}\text { Peningkatan } \\
\text { metabolisme } \\
\text { steroid Error! } \\
\text { Bookmark not defined. }\end{array}$ & $\begin{array}{l}\text { Efek steroid } \\
\text { berkurangError! } \\
\text { Bookmark not } \\
\text { defined. }\end{array}$ & $\begin{array}{l}\text { Peningkatan dosis } \\
\text { steroid, } \\
\text { pemantauan kadar } \\
\text { fenitoin }{ }^{\text {Error! Bookmark }} \\
\text { not defined. }\end{array}$ \\
\hline $\begin{array}{l}\text { Parasetamol- } \\
\text { Fenobarbital }\end{array}$ & $2(1,10 \%)$ & $\begin{array}{l}\text { Induksi enzim } \\
\text { mikrosomal } \\
\text { hepatik dan } \\
\text { peningkatan }\end{array}$ & $\begin{array}{l}\text { Peningkatan } \\
\text { potensi } \\
\text { hepatotoksisitas } \\
\text { dan penurunan }\end{array}$ & $\begin{array}{l}\text { Tidak perlu } \\
\text { penyesuaian atau } \\
\text { pemantauan pada } \\
\text { dosis terapi oralError! }\end{array}$ \\
\hline
\end{tabular}

Facts tahun 2012. Sementara aktual ADR merupakan efek merugikan yang benar-benar dialami pasien yang diketahui melalui keluhan dan data laboratorium pasien. 
Fivy Kurniawati, et al

Tabel IIIb. Mekanisme Interaki Obat

\begin{tabular}{|c|c|c|c|c|}
\hline Interaksi & $\begin{array}{c}\text { Jumlah (\%) } \\
n=182\end{array}$ & Mekanisme & Efek & Manajemen \\
\hline \multicolumn{5}{|c|}{ Perubahan Ekskresi } \\
\hline $\begin{array}{l}\text { Gentamisin- } \\
\text { Ketorolak }\end{array}$ & $24(13,19 \%)$ & $\begin{array}{l}\text { Akumulasi } \\
\text { gentamisin oleh } \\
\text { ketorolak } \\
\text { dengan } \\
\text { mereduksi } \\
\text { GFRError! Bookmark } \\
\text { not defined. }\end{array}$ & $\begin{array}{l}\text { Konsentrasi } \\
\text { plasma } \\
\text { gentamisin } \\
\text { meningkat } \\
\text { ! Bookmark not } \\
\text { defined. }\end{array}$ & $\begin{array}{l}\text { Dosis gentamisin } \\
\text { diturunkan, fungsi } \\
\text { ginjal dan kadar } \\
\text { gentamisin } \\
\text { dipantau Error! Bookmark } \\
\text { not defined. }\end{array}$ \\
\hline $\begin{array}{l}\text { Furosemid- } \\
\text { Parasetamol }\end{array}$ & $5(2,75 \%)$ & $\begin{array}{l}\text { Penurunan } \\
\text { ekskresi } \\
\text { prostaglandin } \\
\text { ginjal dan } \\
\text { aktifitas plasma } \\
\text { renin Error! Bookmark } \\
\text { not defined. }\end{array}$ & $\begin{array}{l}\text { Penurunan } \\
\text { efek } \\
\text { furosemid Error! } \\
\text { Bookmark not } \\
\text { defined. }\end{array}$ & $\begin{array}{l}\text { Tidak perlu tindakan } \\
\text { khusus }{ }^{\text {Error! Bookmark not }} \\
\text { defined. }\end{array}$ \\
\hline $\begin{array}{l}\text { Kalium Klorida- } \\
\text { Spironolakton }\end{array}$ & $2(1,10 \%)$ & $\begin{array}{l}\text { Penurunan } \\
\text { eliminasi } \\
\text { kalium oleh } \\
\text { ginjalError! Bookmark } \\
\text { not defined. }\end{array}$ & $\begin{array}{l}\text { Hiperkalemia } \\
\text { beratError! } \\
\text { Bookmark not } \\
\text { defined. }\end{array}$ & $\begin{array}{l}\text { Pemantauan } \\
\text { konsentrasi serum } \\
\text { kalium secara } \\
\text { ketatError! } \\
\text { Bookmark not } \\
\text { defined. }\end{array}$ \\
\hline $\begin{array}{l}\text { Aspirin- } \\
\text { Glimepirid }\end{array}$ & $2(1,10 \%)$ & $\begin{array}{l}\text { Penurunan } \\
\text { kadar plasma } \\
\text { glukosa dan } \\
\text { peningkatan } \\
\text { sekresi insulin } \\
\text { oleh salisilat }{ }^{\text {Error! }} \\
\text { Bookmark not defined. }\end{array}$ & $\begin{array}{l}\text { Peningkatan } \\
\text { risiko } \\
\text { hipoglikemia } \\
\text { Error! Bookmark not } \\
\text { defined. }\end{array}$ & $\begin{array}{l}\text { Monitoring kadar } \\
\text { glukosa, jika terjadi } \\
\text { hipoglikemia, dosis } \\
\text { sulfonilurea } \\
\text { diturunkan atau } \\
\text { mengganti aspirin } \\
\text { dengan parasetamol } \\
\text { atau NSAID } \\
\text { lainnyaError! Bookmark not } \\
\text { defined. }\end{array}$ \\
\hline \multicolumn{5}{|l|}{ Farmakodinamik } \\
\hline $\begin{array}{l}\text { Furosemid- } \\
\text { Kaptopril }\end{array}$ & $2(1,10 \%)$ & $\begin{array}{l}\text { Inhibisi } \\
\text { produksi } \\
\text { angiotensin II } \\
\text { oleh ACE } \\
\text { inhibitorError! } \\
\text { Bookmark not defined. }\end{array}$ & $\begin{array}{l}\text { Penurunan } \\
\text { efek loop } \\
\text { diuretik }^{\text {Error! }} \\
\text { Bookmark not } \\
\text { defined. }\end{array}$ & $\begin{array}{l}\text { Pemantauan status } \\
\text { cairan dan berat } \\
\text { badanError! Bookmark not } \\
\text { defined. }\end{array}$ \\
\hline Aspirin-Kaptopril & $2(1,10 \%)$ & $\begin{array}{l}\text { Penghambatan } \\
\text { sintesis } \\
\text { prostaglandin Err } \\
\text { or! Bookmark not defined. }\end{array}$ & $\begin{array}{l}\text { Pengurangan } \\
\text { efek } \\
\text { hipotensi dan } \\
\text { vasodilator } \\
\text { dari } \\
\text { kaptoprilError! } \\
\text { Bookmark not } \\
\text { defined. }\end{array}$ & $\begin{array}{l}\text { Menurunkan dosis } \\
\text { aspirin atau } \\
\text { mengubah captopril } \\
\text { menjadi angiotensin } \\
\text { receptor blockerError! } \\
\text { Bookmark not defined. }\end{array}$ \\
\hline
\end{tabular}


Tabel IIIc. Mekanisme Interaki Obat

\begin{tabular}{|c|c|c|c|c|}
\hline Interaksi & $\begin{array}{c}\text { Jumlah (\%) } \\
n=182\end{array}$ & Mekanisme & Efek & Manajemen \\
\hline $\begin{array}{l}\text { Ampisillin- } \\
\text { Gentamisin }\end{array}$ & $14(7,69 \%)$ & $\begin{array}{l}\text { Unknown } \\
\text { Bookmark not } \\
\text { defined. }\end{array}$ & $\begin{array}{l}\text { Inaktivasi } \\
\text { aminoglikosida } \\
\text { oleh } \\
\text { penisilin Error! } \\
\text { Bookmark not defined. }\end{array}$ & $\begin{array}{l}\text { Hindari } \\
\text { pencampuran } \\
\text { aminoglikosida dan } \\
\text { penisilin, } \\
\text { pemantauan } \\
\text { konsentrasi } \\
\text { aminoglikosida dan } \\
\text { fungsi renalError! } \\
\text { Bookmark not defined. }\end{array}$ \\
\hline $\begin{array}{l}\text { Asam Folat- } \\
\text { Fenitoin }\end{array}$ & $4(2,20 \%)$ & $\begin{array}{l}\text { Unknown } \\
\text { Borror! } \\
\text { defined. }\end{array}$ & $\begin{array}{l}\text { Penurunan } \\
\text { konsentrasi } \\
\text { serum fenitoin, } \\
\text { penurunan efek } \\
\text { farmakologis }{ }^{\text {Error! }} \\
\text { Bookmark not defined. }\end{array}$ & $\begin{array}{l}\text { Pemantauan } \\
\text { konsentrasi serum } \\
\text { fenitoin. Penyesuaiar } \\
\text { dosis fenitoin. Error! } \\
\text { Bookmark not defined. }\end{array}$ \\
\hline $\begin{array}{l}\text { Aspirin- } \\
\text { Furosemid }\end{array}$ & $2(1,10 \%)$ & $\begin{array}{l}\text { Unknown } \\
\text { Bookmark not } \\
\text { defined. }\end{array}$ & $\begin{array}{l}\text { Respon diuretik } \\
\text { terhadap } \\
\text { furosemid } \\
\text { terganggu } \\
\text { Bookmark not defined. }\end{array}$ & $\begin{array}{l}\text { Tidak memerlukan } \\
\text { tindakan khusus }{ }^{\text {Error! }} \\
\text { Bookmark not defined. }\end{array}$ \\
\hline $\begin{array}{l}\text { Diklofenak- } \\
\text { Ranitidin }\end{array}$ & $2(1,10 \%)$ & $\begin{array}{l}\text { Unknown } \\
\text { Brror! } \\
\text { Bookmark not } \\
\text { defined. }\end{array}$ & $\begin{array}{l}\text { Perubahan efek } \\
\text { terapetik } \\
\text { diklofenak } \\
\text { Brror! } \\
\text { Bookmark not defined. }\end{array}$ & $\begin{array}{l}\text { Tidak memerlukan } \\
\text { tindakan khusus } \\
\text { Brror! } \\
\text { Bookmark not defined. }\end{array}$ \\
\hline $\begin{array}{l}\text { Pirazinamid- } \\
\text { Rifampisin }\end{array}$ & $2(1,10 \%)$ & $\begin{array}{l}\text { Unknown } \\
\text { Brror! } \\
\text { Bookmark not } \\
\text { defined. }\end{array}$ & $\begin{array}{l}\text { Penurunan } \\
\text { kadar serum } \\
\text { rifampisin } \\
\text { sehingga efek } \\
\text { klinis } \\
\text { berkurangError! } \\
\text { Bookmark not defined. }\end{array}$ & $\begin{array}{l}\text { Tidak memerlukan } \\
\text { tindakan khusus. } \\
\text { Mungkin } \\
\text { peningkatan dosis } \\
\text { rifampisin Error! Bookmark } \\
\text { not defined. }\end{array}$ \\
\hline $\begin{array}{l}\text { Amikasin - } \\
\text { Sefotaksim }\end{array}$ & $2(1,10 \%)$ & $\begin{array}{l}\text { Unknown } \\
\text { Brror! } \\
\text { Bookmark not } \\
\text { defined. }\end{array}$ & $\begin{array}{l}\text { Peningkatan } \\
\text { nefrotoksisitas } \\
\text { dan aktivitas } \\
\text { bakterisidal }^{\text {Error! }} \\
\text { Bookmark not defined. }\end{array}$ & $\begin{array}{l}\text { Pemantauan kadar } \\
\text { aminoglikosida dan } \\
\text { fungsi ginjal, } \\
\text { penurunan dosis } \\
\text { star nonchontisn }\end{array}$ \\
\hline
\end{tabular}

Hasil penelitian menunjukkan potensial ADRs dialami oleh 51 pasien pediatri, 70 pasien dewasa dan 61 pasien geriatri. Dikategorikan sebagai potensial ADR karena tidak terdapat keluhan dan tidak ada data laboratorium/uji lainnya sehingga ADR aktual tidak dapat dinilai. Potensial ADR yang terjadi berupa perubahan konsentrasi plasma, inaktivasi obat lain (aminoglikosida), perubahan efek terapi atau farmakologi dari obat lainnya, nefrotoksisitas, hepatotoksisitas, hiperkalemia, depresi sistem saraf pusat dan perubahan kadar gula darah (hiperglikemia/hipoglikemia).

Adapun aktual ADR merupakan efek merugikan yang dialami pasien akibat interaksi obat yang diketahui melalui keluhan, tanda-tanda vital dan uji laboratorium pasien. Aktual ADR yang terjadi adalah 3,3\% yakni 2 pasien pediatri dan 4 pasien geriatri. 
Fivy Kurniawati, et al

Tabel IV. Aktual Adverse Drug Reactions

\begin{tabular}{lcll}
\hline \multicolumn{1}{c}{ Interaksi Obat } & Jumlah & \multicolumn{1}{c}{ Aktual ADRs } & Keluhan/Data Lab \\
\hline $\begin{array}{l}\text { Asam valproat- } \\
\begin{array}{l}\text { Asiklovir } \\
\text { Ketorolak-Ranitidin }\end{array}\end{array}$ & 1 & $\begin{array}{l}\text { Penurunan konsentrasi serum } \\
\text { dan efek asam valproat }\end{array}$ & Kejang \\
$\begin{array}{l}\text { Glimepirid-Ketokonazol } \\
\text { Alprazolam-Teofilin }\end{array}$ & 1 & $\begin{array}{l}\text { Perubahan aksi terapi NSAID } \\
\text { Hipoglikemia }\end{array}$ & $\begin{array}{l}\text { Mual dan muntah } \\
\text { Penurunan GDP } \\
\text { Penurunan efek sedatif } \\
\text { benzodiazepin }\end{array}$ \\
$\begin{array}{l}\text { Furosemide- } \\
\text { Parasetamol }\end{array}$ & 2 & Penurunan efek furosemid & $\begin{array}{l}\text { Peningkatan tekanan } \\
\text { darah }\end{array}$ \\
\hline
\end{tabular}

Penelitian lain menunjukkan bahwa tidak ada aktual ADRs yang terjadi terkait interaksi obat. ${ }^{18}$

Interaksi asam valproat dan asiklovir menghasilkan efek penurunan konsentrasi serum asam valproat yang menyebabkan penurunan aktivitas obat. ${ }^{18}$, 36 Penurunan konsentrasi serum valproat dapat meningkatkan frekuensi kejang serta sebuah penelitian melaporkan interaksi tersebut terjadi pada dua anak yang diberikan asiklovir dan asam valproat secara bersamaan. ${ }^{22}$ Kejadian ADRs berupa kejang (Tabel IV) terjadi pada pasien dengan diagnosis encephalitis yang sebelumnya terkontrol dengan asam valproat $375 \mathrm{mg} / 12$ jam diatasi dengan penyesuaian dosis asam valproat berupa peningkatan dosis menjadi $500 \mathrm{mg} / 12$ jam.

Ketorolak merupakan jenis NSAID yang paling sering digunakan dan $\mathrm{H} 2$ bloker merupakan obat yang paling sering diberikan bersamaan dengan NSAID sebagai gastroprotektif.19, 26 Perubahan efek yang mungkin terjadi pada penggunaan ketorolak dan ranitidin yakni nyeri epigastrik, mual, sakit kepala, pusing dan ruam kulit. Salah seorang pasien dengan diagnosis penis tenggelam mendapatkan terapi ketorolak dan ranitidin kemudian mengeluhkan mual muntah (Tabel IV). Pengatasan berupa pemberian terapi tambahan ondansetron juga penghentian kombinasi ketorolak dan ranitidin.

Glimepirid merupakan anti diabetes golongan sulfonilurea yang paling banyak digunakan untuk mengobati DM tipe II. ${ }^{37,} 38$ Sulfonilurea memiliki bioavabilitas yang tinggi, terikat kuat pada protein, dan dimetabolisme di hati oleh enzim CYP 2C9.23 Pasien dengan diagnosis stroke mengalami hipoglikemia severe yang semula $100 \mathrm{mg} / \mathrm{dL}$ menjadi $39 \mathrm{mg} / \mathrm{dL}$ setelah diberikan kombinasi glimepirid-ketokonazol. Penggunaan glimepirid sebagai monoterapi akan menyebabkan hipoglikemia dan adanya kombinasi dengan ketozonazole sebagai inhibitor enzim CYP 2C9 akan meningkatkan efek hipoglikemia tersebut. ${ }^{23,} 24$ Pengatasan efek tersebut dilakukan dengan memberikan dekstrosa IV diikuti karbohidrat kompleks.

Penggunaan alprazolam bersama teofilin akan menurunkan kadar alprazolam yang menyebabkan penurunanan efek benzodiazepin terutama efek sedatif. ${ }^{18,} 22$ Mekanisme interaksinya terjadi secara farmakodinamik, yaitu teofilin memblokir reseptor adenosin dan menginduksi metabolisme benzodiazepin oleh hati sehingga kadarnya berkurang. ${ }^{22}$ Salah seorang pasien dengan diagnosis PPOK mengeluhkan sulit tidur setelah mengonsumsi alprazolam dan teofilin secara bersamaan. Keluhan sulit tidur (efek merugikan) diduga sebagai ADR aktual.

Furosemid merupakan diuretik yang bekerja menghambat reabsorpsi natrium pada tubulus ginjal yang menghasilkan peningkatan ekskresi natrium dan urin. Selain itu furosemid juga meningkatkan ekskresi prostaglandin pada ginjal. Adanya parasetamol akan menghambat biosintesis 
prostaglandin yang dapat menurunkan ekskresi natrium dan menyebabkan hipertensi.23, 39 Peningkatan tekanan darah akibat interaksi furosemid-parasetamol terjadi pada dua pasien geriatri. Pasien dengan diagnosis diabetes mellitus dan anemia mengeluhkan pusing yang didukung dengan pemeriksaan tekanan darah pasien dari 110/64 mmHg menjadi 148/70 mmHg dan 144/71 mmHg. Namun peningkatan tekanan darah tersebut juga dapat dipengaruhi oleh obatobatan lain yang dikonsumsi pasien yaitu pantoprazol dan aspirin. Hal yang serupa juga dialami oleh pasien yang lain dengan diagnosis Benign Prostatic Hyperplasia, terjadi peningkatan tekanan dari 110/80 menjadi 150/70 dan dari 130//80 mmHg menjadi 170/100 mmHg.

Penelitian ini dilakukan secara retrospektif dengan pengambilan data menggunakan data rekam medik pasien rawat inap RS Akademik UGM periode Januari-Juni 2018. Penggunaan obat, perkembangan pasien, keluhan dan data laboratorium terkait interaksi obat dan ADRs hanya berdasarkan data yang tercatat pada rekam medik pasien. Catatan rekam medik pasien tidak mencantumkan hasil laboratorium secara berkala selama pasien menjalani rawat inap dan sebagian besar uji laboratorium hanya dilakukan satu kali. Hal ini menyebabkan keterbatasan dalam menganalisis ADR terkait interaksi obat pada pasien.

\section{KESIMPULAN}

Kejadian interaksi obat yang potensial terjadi pada pasien rawat inap RS Akademik UGM periode Januari-Juni 2018 yaitu sebanyak 115 dari 362 pasien (31,8\%) dengan jumlah kejadian interaksi sebanyak 182 interaksi obat. Jenis interaksi obat yang paling banyak terjadi adalah interaksi moderate sejumlah 115 interaksi (63,2\%) sedangkan jumlah mekanisme paling banyak adalah unknown $(54,4 \%)$. Terdapat 6 pasien $(3,3 \%)$ yang mengalami aktual ADRs terkait interaksi obat.

\section{DAFTAR PUSTAKA}

1. BPOM. Pedoman Monitoring Efek Samping Obat (MESO) Bagi Tenaga Kesehatan. Badan POM RI. https://emeso.pom.go.id/web/useruploads/files/ reference $/ 562$

75c6f030ff_PEDOMAN\%20MESO_NA

KES.pdf. Dipublikasikan 2012. Diakses 2 Juli 2019.

2. Sindhu MS, Kannan B. Investigating The Factors Affecting Drug-Drug Interactions. Int $J$ Pharm Bio Sci. 2013;4(4):(P) 467 - 476.

3. Kaufman G. Adverse Drug Reactions: Classification, Susceptibility and Reporting. Nurs. Stand. 2016;30:53-63.

4. Namazi S, Pourhatami S, BorhaniHaghighi A, Roosta S. Incidence of Potential Drug-Drug Interaction and Related Factors in Hospitalized Neurological Patients in two Iranian Teaching Hospitals. Iran J Med Sci. 2014;39(6):515-521.

5. Bucsa C, Farca A, Cazacu I, et al. How Many Potential Drug - Drug Interactions Cause Adverse Drug Reactions in Hospitalized Patients?. European Journal of Internal Medicine. 2013;24:27-33.

6. Magro L, Moretti U, Leone $\mathrm{R}$. Epidemiology and Characteristics of Adverse Drug Reactions caused by Drug-Drug Interactions. Expert Opinion Drug Saf. 2012; 11:83-94.

7. Shibbiru T, Tadesse F. Adverse Drug Reactions: An Overview. J Med Physiol Biophys. 2016;(23):(P) 7-14.

8. Dai D, Feinstein JA, Morrison W, Zuppa F, Feudtner C. Epidemiology of Polypharmacy and Potential DrugDrug Interactions among Pediatric Patients in Intensive Care Units of U.S. Pediatr Crit Care Med. 2017;17(5):pp. e218-e228.

9. Percha B, Altman RB. Informatics Confronts Drug-Drug Interactions. Trends in Pharmacological Sciences. 
Fivy Kurniawati, et al

2013;34(3):178-184.

10. Juarez-Cedillo T, Martinez-Hernandez C, Hernandez-Constantino A, et al. Clinical Weighting of Drug-Drug Interactions in Hospitalized Elderly. Basic Clininical Pharmacol Toxicol. 2016;(118):(P) 298-305.

11. Furdiyanti NH, Luhurningtyas FP, Sari $\mathrm{R}$, et al. Evaluasi Dosis dan Interaksi Obat Antidiabetika Oral pada Pasien Diabetes Mellitus Tipe II. Jurnal Manajemen dan Pelayanan Farmasi. 2017;7(4):(P) 191-196.

12. Feinstein J, Dai D, Zhong W, Freedman J, Feudtner, C. Potential Drug-Drug Interactions in Infant, Child, and Adolescent Patients in Children's Hospitals. PEDIATRICS. 2014;135(1):e99-e108.

13. Faizah AK. Kajian Interaksi Obat pada Pasien Pneumonia di RS Pendidikan Surabaya. Jurnal Scientia. 2018;8(1):8691.

14. Hendera, Rahayu S. Interaksi Antar Obat pada Peresepan Pasien Rawat Inap Pediatrik Rumah Sakit $X$ dengan Menggunakan Aplikasi Medscape. JPCS. 2018;1(2): 75-80.

15. Morales-Rõ̂Aos O, Jasso-GutieÂrrez L, Reyes-LoÂpez A, et al. Potential DrugDrug Interactions and Their Risk Factors in Pediatric Patients Admitted to The Emergency Department of a Tertiary Care Hospital in Mexico. PLoS ONE. 2018;13(1):e0190882.

16. Cho CM, Lee YM. The Relationship Between Cardiovascular Disease Risk Factors and Gender. Health. 2012; 4(6):(P)309-315.

17. Faizah AK. Kajian Interaksi Obat pada Pasien Pneumonia di RS Pendidikan Surabaya. Jurnal Scientia. 2018;8(1):8691.

18. Hassanzad M, Arenas-lopez S, Baniasadi S. Potential Drug - Drug Interactions Among Critically Ill Pediatric Patients in a Tertiary. The Journal of Clinical Pharmacology. 2017;00(0):pp.1-7.
19. Saiyed MM, Lalwani T, Rana D. OffLabel Medicine Use in Pediatric Inpatients: A Prospective Observational Study at a Tertiary Care Hospital in India. International Journal of Pediatrics. 2014;_:p. 6 pages.

20. Ismail $\mathrm{M}$, Iqbal $\mathrm{Z}$, Khan $\mathrm{MI}$, et al. Frequency, Levels and Predictors of Potential Drug-Drug Interactions in a Pediatrics Ward of a Teaching Hospital in Pakistan. Trop J Pharm Res. 2013;12(3):401-406.

21. Nabovati E, Vakili-arki H, Taherzadeh $\mathrm{Z}$, et al. Drug-Drug Interactions in Inpatient and Outpatient Settings in Iran : a Systematic Review of the Literature. DARU Journal of Pharmaceutical Sciences. 2014;22:52.

22. Murtaza G, Khan MY, Azhar S, et al. Assessment of Potential Drug-Drug Interactions and Its Associated Factors in The Hospitalized Cardiac Patients. Saudi pharmaceutical journal: the official publication of the Saudi Pharmaceutical Society. 2016;24(2):220-225.

23. George AS, Ramesh M, Sebastian J. Adverse Drug Reactions in Elderly Hospitalized Patients: A Prospective Analysis. Int $J$ Pharm Sci Res. 2018;9(5):(P) 13-20.

24. Rashed A, Mohammed WA, Marwan AE, Fahad AA, Alqarni M, Maimsh O, Aljefri HM. Medication Safety Practice in Pediatric Ward. The Egyptian Journal of Hospital Medicine. 2018;71(5):pp. 32363240 .

25. Cristina M, Rodrigues S, Oliveira C. Drug-Drug Interactions and Adverse Drug Reactions in Polypharmacy among Older Adults: An Integrative Review. Rev Latino-Am Enferm. 2016;(24):(P) 1-17.

26. Reis AM, Cassiani SH. Prevalence of Potential Drug Interactions in Patients in an Intensive Care Unit of a University Hospital in Brazil. Clinics (Sao Paulo). 2011;66(1):9-15.

27. Masukawa MY, Veríssimo GB, Vianello $\mathrm{MH}$, et al. Drug Interactions in Children 
with Respiratory Diseases in the Pediatric Unit of a Teaching Hospital in Brazil. Revista Cubana de Pediatría. 2016;88(2):166-181.

28. Yanti E, Kristin E, Yasmina A. Potential Drug Interactions in Hypertensive Patients in Liwa District Hospital, Lampung Barat, Indonesia. International Journal of Pharmacy and Pharmaceutical Sciences. 2017;9(6):134-138.

29. Guerzoni S, Lanfranco P. Alberto PL, et al. Drug-Drug Interactions in The Treatment for Alcohol Use Disorders. Pharmacol. Res. 2018;133:65-76.

30. Teixeira JJ, Crozatti MT, dos Santos CA, et al. Potential Drug-Drug Interactions in Prescriptions to Patients Over 45 years of Age in Primary Care, Southern Brazil. PloS one. 2012;7(10):e47062.

31. Sjahadat AG, Muthmainah SS. Analisis Interaksi Obat Pasien Rawat Inap Anak di Rumah Sakit di Palu. Jurnal Farmasi Klinik Indonesia. 2013;2(4):pp. 1-6.

32. Tatro DS. Drug Interaction Facts. California: Wolters Kluwer Health Inc, 2012.

33. Kibrom S, Tilahun Z, Huluka SA. Potential Drug-Drug Interactions among Adult Patients Admitted to
Medical Wards at a Tertiary Teaching Hospital in Ethiopia. Journal of Drug Delivery and Therapeutics. 2018;8(5s):348-354.

34. Maheshwari P, Praveen D, Ravichandiran V. Adverse Drug Reactions of NSAIDs in General Care Hospital. Asian Journal of Pharmaceutical and Clinical Research. 2014;7(3):69-71.

35. Greener M. Understanding Adverse Drug Reactions: An Overview. Nurse Prescribing. 2014;12(4):189-195.

36. Baxter K. Stockley's Drug Interactions : A Source Book of Interactions, Their Mechanism, Clinical Importance and Management. London: Pharmaceutical Press, 2010.

37. May M, Schindler C. Clinically and Pharmacologically Relevant Interactions of Antidiabetic Drugs. Ther. Adr. Endocrinol.Metab. 2016;7(2):69-83.

38. Gunaratne K, Austin E, Wu PE. Uninternational Sulfonylurea Toxicity due to a Drug-Drug Interaction : A Case Report. BMC Res. Notes. 2018;11(331):13.

39. Oh SW, Han SY. Loop Diuretics in Clinical Practice. The Korean Society of Electrolyte Metabolism. 2015;13(1):17-21. 